\title{
Planning, development, monitoring and evaluation of the Academia da Cidade do Recife action plan during COVID-19
}

\author{
Planejamento, desenvolvimento, monitoramento e avaliação do plano de ação do \\ Academia da Cidade do Recife durante a COVID-19
}

\author{
AUTHOR'S \\ Danyelle de Cássia Ribeiro de Oliveira ${ }^{1}$ (I) \\ Tatiana Martins Ferraz Holmes ${ }^{1}$ (D) \\ Emmanuelly Correia de Lemos ${ }^{2,3}$ (D) \\ Rafael Miranda Tassitano $0^{4,5}$ (D) \\ Raquel Bezerra Pajeú ${ }^{1}$ (D) \\ Gledson da Silva Oliveira ${ }^{1}$ (D) \\ Luiz Eduardo Nunes de Souza ${ }^{1}$ (ID \\ Renan Wallacy Yvson dos Santos ${ }^{1}$ (D) \\ Charles Barbosa Gomes da Silva ${ }^{1}$ (D) \\ Marcílio Paulo da Silva ${ }^{1}$ (D) \\ Gabriela Maranhão Câmara Campos ${ }^{1}$ (D) \\ Ricardo Augusto Menezes da Silva ${ }^{1}$ (D) \\ 1 Programa Academia da Cidade. Secretaria \\ Municipal de Saúde do Recife, Pernambuco, Brasil. \\ 2 Escola de Governo em Saúde Pública de \\ Pernambuco. Secretaria Estadual de Saúde de \\ Pernambuco, Brasil \\ 3 Escola Superior de Educação Física, Universidade \\ de Pernambuco Grupo de Pesquisa em Estilos de \\ Vida e Saúde, Recife, Pernambuco, Brasil. \\ 4 Universidade Federal Rural de Pernambuco, \\ Recife, Pernambuco, Brasil. \\ 5 Programa de Pós-Graduação em Educação Física \\ da Universidade de Pernambuco/Universidade \\ Federal da Paraíba, Brasil.
}

\section{CORRESPONDING}

Danyelle de Cássia Ribeiro de Oliveira pacdistrito8@gmail.com

Avenida Beberibe, nº3530/B1-B7, Apt ${ }^{\circ} 103$,

Porto da Madeira, Recife, Pernambuco, Brasil. CEP: 50100-130.

DOI

$10.12820 /$ rbafs. $25 \mathrm{e} 0160$

\section{(c) BY}

This work is licensed under a Creative Commons Attribution 4.0 International License.

\begin{abstract}
The aim of the study was to describe the Programa Academia da Cidade do Recife (PAC-REC) action plan during the social isolation requirement due to the COVID-19 pandemic. This is a descriptive study, of the type of experience report on the construction and implementation of the PAC-REC action plan, Pernambuco, during the COVID-19 pandemic. The plan was built in six stages distributed between planning (first and second), development (third and fourth) and monitoring and evaluation (fifth and sixth). To describe the experience, the minutes of meetings, the online monitoring files of the Program were used. The final action plan, after it was composed of three axes: monitoring of actions, support actions in the territory and core actions of the PAC-REC. Even in the face of the pandemic, PAC-REC built and implemented its plan, continuing and expanding its health promotion actions for recifenses.
\end{abstract}

Keywords: Motor activity; Health promotion; COVID-19; Social isolation, Public policy.

RESUMO

O objetivo desse artigo foi descrever a construção e implantação do plano de ação do Programa Academia da Cidade Recife (PAC-REC) durante o periodo de isolamento social devido a COVID-19. Trata-se de um estudo descritivo, do tipo relato de experiência sobre a construção e da implementação do plano de ação PAC-REC, Pernambuco, durante a pandemia de COVID-19. O plano foi construído em seis etapas distribuidas entre o planejamento (primeira e segunda), desenvolvimento (terceira e quarta) e monitoramento e avaliação (quinta e sexta). Para descrição da experiência foram utilizadas as atas de reuniōes, os arquivos online de monitoramento do Programa. O plano de ação final, após foi composto por três eixos: monitoramento das ações, ações de apoio no território e ações de núcleo do PAC. Mesmo diante da pandemia o PAC-REC construiu e implantou o seu plano, dando continuidade e ampliando as suas açôes de promoção à saúde para os recifenses.

Palavras-chave: Atividade motora; Promoção da saúde; COVID-19; Isolamento social; Política pública.

\section{Introduction}

The government of the city of Recife implemented the Programa Academia da Cidade de Recife/Pernambuco (PAC-REC) in $2002^{1}$, aimed to provide access 
and universalization of public health promotion. It is important to notice that the tenets of the PAC-REC are based on the Health Promotion National Policy (HPNP) and the Primary Care National Policy $(\mathrm{PCNP})^{2,3}$.

Over almost 20 years, the PAC-REC has been developing actions to improve the collective health promotion, such as physical activities, physical fitness assessment, cultural events related to the health calendar, social control, health education and enhancement of the public environment ${ }^{1,4}$. Data from PAC-REC indicated that about 604,352 public utilizations of these actions during 2019.

In March of 2020, the World Health Organization (WHO) declared the COVID-19 as pandemic level, and since then, unprecedented consequences have been observed in several areas, such as biomedical, epidemiological, social, politics, and cultural ${ }^{5}$. Due to the total confirmed infected cases and deaths related to COVID-19, several restrictions on social mobility have been implemented worldwide ${ }^{5}$ and among several states from Brazil (i.e. Pernambuco State - n 48.822 ${ }^{6}$ ). Then, the Capital of the Pernambuco State published the coping actions in its contingency plan, which contained the suspension of services considered non-essential, including the presential classes of the PACREC program ${ }^{7}$.

Considering the PAC-REC's commitment to the Unified Health System (SUS) and the Primary Health Care (PHC), and in order to continue offering health promotion actions in the territory, and also to provide its users with the empowerment to support self-care, presenting itself as an important tool for promoting health and guaranteeing fundamental human rights ${ }^{2,3}$, the PAC-REC core management group developed an action plan, restructuring its potential for action through the reorganization of remote activities offered to the users of the Program. In this sense, this study aims to describe the construction and implementation of the PAC action plan during the period of social isolation due to the COVID-19.

\section{Methods}

This manuscript presents an experience of building and implementing the action plan of the PAC-REC during the COVID-19 Pandemic. The action plan has six stages encompassing planning (first and second), development (third and fourth), monitoring and evaluation (fifth and sixth). The whole process started in March
2020 and will continue as long as the COVID-19 pandemic lasts. The logical model of the PAC-REC action plan in the context of Pandemic is presented in Chart 1.

\section{Results and discussion}

The purpose of this manuscript was to present the action plan of PAC-REC developed during the COVID-19 pandemic period. Thus, a board committee was established to elaborate the document (6 stages) just after the decree suspending the presential activities of the program. The first stage included the mechanis$\mathrm{ms}$ of communication and survey on the functioning of other health promotion programs, in order to prepare a document, communicating on March 17, 2020 to the Physical Educator professionals (PEFs) the government directives, and, guiding them regarding the update of the monthly reports to be carried out at this first moment. Between March and May, a parallel situational diagnosis of similar national programs was carried out.

The second stage included the construction of a set of actions to be developed during the COVID-19 pandemic. In this process, activities that were able to meet the needs of the PAC-REC users requested by the municipal Primary Health Care Network (MPCN) were considered, and all the crucial processes for that time of creation were taken into account, such as planning, development, monitoring and evaluation of the entire framework of actions.

Thus, in April, the first version of the PAC's Remote Activities Action Plan was organized, mostly containing remote activities, transposing the maximum possible activities that were presential at the Program's hubs. Still, some face-to-face activities coexisted in order to support the territory. It is noteworthy that there were some contributions from other health network actors, particularly the e-SUS report due to some unprecedented and special situations that were experienced in this period. Subsequently, there were some updates to this Action Plan (April to June 2020).

The third stage comprised the entire distribution mechanism of the Action Plan for the PEPs of the PAC, to the managers of the Executive Board of Primary Care and District Management (EBPCDM) and the Program's users. A presentation and a distribution agenda among the PEPs of the PAC-REC were organized, using district meetings between the eight technical-pedagogical coordinators and their respective teams. The moments of the district meetings served to 
Chart 1 - Logical Model of the PAC-REC action plan during COVID-19 pandemic, Recife, Pernambuco, 2020.

Problem: Lockdown of PAC-REC activities due the COVID-19 pandemic.

Answer problem: Remote activity plan of the Academy Program of the City of Recife (PAC-REC) during the pandemic COVID-19.

Global aim: To maintain PAC's health promotion, risk prevention and health problems actions through remote activities.

Target audience: Professionals and users of the Academia da Cidade Program, Recife, Permanbuco.

\begin{tabular}{|c|c|c|c|c|c|}
\hline Input & $\begin{array}{c}\text { Core } \\
\text { component }\end{array}$ & Objective & Activities & Products & Results \\
\hline $\begin{array}{l}10 \text { professionals } \\
\text { from the } \\
\text { Management } \\
\text { Center (MC) }\end{array}$ & Planning & $\begin{array}{l}\text { Identify the possible actions } \\
\text { to be taken by the PAC } \\
\text { during the pandemic. } \\
\text { Structure the actions, goals } \\
\text { and expected results of the } \\
\text { PAC's performance during } \\
\text { the pandemic. }\end{array}$ & $\begin{array}{l}\text { Survey with other Physical Activity } \\
\text { Promotion programs on the status } \\
\text { of activities developed during social } \\
\text { isolation. } \\
\text { Weekly meetings of the PAC MC } \\
\text { to prepare the Action Plan. } \\
\text { Organization of working groups } \\
\text { between MC and professionals } \\
\text { from the PAC hubs to systematize } \\
\text { the plans actions. }\end{array}$ & $\begin{array}{l}\text { Survey of } 3 \text { Physical Activity } \\
\text { Promotion Programs to verify } \\
\text { successful experiences as an } \\
\text { inspiration for organizing the } \\
\text { Action Plan. } \\
2 \text { MC meetings held to build the } \\
\text { action plan. } \\
6 \text { working groups organized in } \\
\text { order to structure and systematize } \\
\text { the action plan. }\end{array}$ & $\begin{array}{l}\text { Action Plan } \\
\text { built and } \\
\text { implemented } \\
\text { with the } \\
\text { maintenance } \\
\text { of the PAC } \\
\text { activities both } \\
\text { presential and } \\
\text { remotely. }\end{array}$ \\
\hline $\begin{array}{l}155 \text { Physical } \\
\text { Education } \\
\text { Professionals, } \\
\text { Computer and } \\
\text { Internet }\end{array}$ & Development & $\begin{array}{l}\text { To continue offering PAC } \\
\text { activities to its users remotely. } \\
\text { To gather PAC users more } \\
\text { closely in times of social } \\
\text { isolation. } \\
\text { To maintain and / or improve } \\
\text { the level of physical activity } \\
\text { of users without leaving } \\
\text { home. } \\
\text { To promote the } \\
\text { development of the MC, } \\
\text { its professionals and users } \\
\text { regarding information and } \\
\text { communication technologies }\end{array}$ & $\begin{array}{l}\text { Recording classes for the } \\
\text { Movimenta Recife App } \\
\text { Support of USF campaign actions } \\
\text { Support the flu vaccine campaign } \\
\text { actions } \\
\text { Educational action in the territory } \\
\text { Support in health surveillance } \\
\text { actions (Territorialization - } \\
\text { database analysis) } \\
\text { Support in health surveillance } \\
\text { actions (tele monitoring of users } \\
\text { assisted in Atende em Casa App) } \\
\text { Support in the health surveillance } \\
\text { actions } \\
\text { Physical activity classes and CAP } \\
\text { body practices (live or recorded) } \\
\text { Carrying out health education } \\
\text { actions (live or recorded) } \\
\text { Production of educational material } \\
\text { Conducting remote individual } \\
\text { user's service } \\
\text { Remote meetings between PEPs } \\
\text { and its users (planning, work } \\
\text { process and others) } \\
\text { Meetings within the teams, and } \\
\text { with other intersectoral teams } \\
\text { Planning, development, monitoring } \\
\text { and evaluation of the Programa } \\
\text { Academia da Cidade do Recife } \\
\text { action plan in the COVID-19 } \\
\text { Continuing Education (live, } \\
\text { recorded and / or distance learning } \\
\text { courses) }\end{array}$ & $\begin{array}{l}20 \text { moments of recordings for the } \\
\text { Movimenta Recife APP by the } \\
\text { PAC's PEPs } \\
235 \text { participations of the vaccine } \\
\text { campaign actions by the by the } \\
\text { PAC's PEPs } \\
34 \text { Actions to support the USF by } \\
\text { the PAC's PEPs } \\
129 \text { Educational actions in the } \\
\text { territory carried out by the PAC's } \\
\text { PEPs } \\
59 \text { Support activities for } \\
\text { health surveillance actions } \\
\text { (Territorialization - database } \\
\text { analysis) } \\
1,155 \text { Individual assistance in } \\
\text { tele-monitoring of users served in } \\
\text { the Atende em Casa APP by the } \\
\text { PAC's PEPs } \\
\text { 2,332 Physical activity classes and } \\
\text { body practices performed remotely } \\
\text { (live, and recorded) } \\
\text { 1,331 Health education actions } \\
\text { carried out remotely (live and } \\
\text { recorded) } \\
1,849 \text { Static educational materials } \\
\text { made available to users } \\
\text { 2,959 Individual assistance to users } \\
\text { carried out remotely by the PAC's } \\
\text { PEPs } \\
\text { 273 Meetings with users using } \\
\text { digital platform (planning, work } \\
\text { process and others) } \\
426 \text { Meeting within teams, with } \\
\text { other intersectoral teams } \\
1 \text { systematic document on EAD for } \\
\text { the PAC's PEPs } \\
3 \text { Permanent Health Education } \\
\text { Meetings for the PAC's PEPs (in } \\
\text { progress) }\end{array}$ & \\
\hline $\begin{array}{l}155 \text { Physical } \\
\text { Education } \\
\text { Professionals, } \\
\text { Computer } \\
\text { programs, } \\
\text { Internet, } \\
\text { Tablets }\end{array}$ & Monitoring & $\begin{array}{l}\text { To organize the plan for } \\
\text { monitoring and evaluating } \\
\text { the activities planned } \\
\text { and developed during the } \\
\text { pandemic period from the } \\
\text { action plan. } \\
\text { To update records of } \\
\text { activities carried out by the } \\
\text { PAC before and during the } \\
\text { pandemic period } \\
\text { To qualify the actions } \\
\text { developed by PAC during the } \\
\text { pandemic. }\end{array}$ & $\begin{array}{l}\text { Meeting to organize the } \\
\text { monitoring and evaluation of the } \\
\text { action plan. } \\
\text { Adjustments to the PAC's monthly } \\
\text { reports, adapting them to the reality } \\
\text { of the activities developed remotely. } \\
\text { Organization of an instruction } \\
\text { for each report: Monitor PAC, } \\
\text { e-SUS and Action Plan Report } \\
\text { with guidance for completing the } \\
\text { activities developed. } \\
\text { Completion of PAC reports } \\
\text { Insertion of physical evaluations } \\
\text { performed in the PAC Physical } \\
\text { Evaluation database } \\
\text { Insertion of all activities in e-SUS } \\
\text { Conducting an evaluation and } \\
\text { improvement meeting. } \\
\text { Dissemination of the partial results } \\
\text { of the activities implemented by the } \\
\text { action plan. }\end{array}$ & $\begin{array}{l}1 \text { monthly meeting held to adjust } \\
\text { and update the action plan. } \\
1 \text { monthly meeting held to review } \\
\text { the reports already used in the } \\
\text { PAC: MonitoraPAC and e-SUS, } \\
\text { and structuring of the specific } \\
\text { report for the measures of the } \\
\text { Action Plan. } \\
3 \text { instructions for the reports used } \\
\text { in the PAC in order to qualify the } \\
\text { insertion of information in the } \\
\text { monthly reports of the PAC. } \\
\text { Records of the activities carried out } \\
\text { by the Program. } \\
\text { Physical assessments inserted in the } \\
\text { PAC database. } \\
\text { Update of PAC e-SUS database. } \\
1 \text { monthly monitoring and } \\
\text { evaluation meeting to improve the } \\
\text { activities developed during the } \\
\text { COVID-19 pandemic. } \\
1 \text { quarterly report in bulletin } \\
\text { format, in order to guarantee the } \\
\text { memory and dissemination of the } \\
\text { activities developed. }\end{array}$ & \\
\hline
\end{tabular}

Influencing factors: involvement of PAC's MC and PEPs in all phases of the Action Plan. Users' socioeconomic factors. Social determination of health of the professionals and the users. Perception of professionals regarding their work in the multiprofessional format. Intra and intersectoral integration of PAC. Management support. Quality of social mobilization of users for PAC programming. Digital platform for users' access to PAC's schedules. 
introduce the Action Plan, to align the demands, and to form the six subgroups of work. In sequence, the PEPs introduced it to their users in their respective centers, just as the central level of the Program presented it to the EBPCDM (April to May, 2020)

The fourth stage involved activities focused on the work of the subgroups, and it started in May. As the Action Plan was presented at the district meetings, PEPs were invited to engage in some of the 6 subgroups of work and develop the activities proposed by each one. Each subgroup of work had a responsible representation from the board committee and a group of teachers, in order to organize the two fronts of work that were activities transmitted by teachers directly to users of the respective centers and activities on PAC's REC social networks.

Each work subgroup received a specific logical model for the activities to be developed, in order to guide their production. The groups were: 1) Live body practice classes or recorded classes; 2) Live health education for the users or recorded modes; 3 ) Live permanent education, for professionals or recorded modes; 4) Health Education with a user focus in the form of digital educational material; 5) Individual service focused on users; and 6) Permanent Education for professional using a distance learning course modality.

The fifth stage included the monitoring and evaluation of the Action Plan process by each subgroup during the entire period. The sixth stage included the process of disclosing this report through a bulletin, containing a consolidation of the activities carried out from March to June, from the Action Plan Report database.

The final action plan was composed of three axes: (i) monitoring of actions: monitoring activities that have been happening regularly for several years in the PAC-REC, (ii) supporting actions in the territory: implemented support activities in the PAC to the territory after the suspension of the presential classes at the PAC centers and (iii) core actions in the PAC hubs: activities that took place at PAC-REC centers and were proposed by this Action Plan to be implemented in the remote format (Figure 2).

In the axis of monitoring action, in addition to the reports already systematically filled out such as SUS and MonitoraPAC, there was a need and the construction of a new report to monitor the activities used by the PAC's PEPs, since, in addition to the activities performed remotely, some special activities were necessary. In order to organize the data completion of the e-SUS and MonitoraPAC reports, instructions were built, since all the activities recorded in these reports were designed for activities developed presentially at the PAC centers.

In the axis of supporting actions in the territory, activities such as: (1) participation in video recording classes in the first phase of the Movimenta Recife APP, (2) face-to-face support related to H1N1 flu vaccine campaigns, (3) administrative support to the Family Health Units (FHU), (3) COVID-19 educational action in the territory, (4) support for the Atende em casa APP were included, both in the territorial analysis of the user and in the monitoring of this APP's users.

In the axis iii - core actions in the PACs hubs- some products had to be systematized to organize work and ensure alignment between the professionals: (1) Document guiding the remote activities related to the common activities to be developed for all of the PACREC, (2) Guiding document for the completion of the PAC's monthly reports, (3) Document containing a collection of free distance learning courses to qualify the work developed by the PEPs, (4) Support document for individual consultation, containing a list of places that the professionals could refer the users to in the health network or in other sectors, if necessary, (5) Guiding document for the production of videos and live by the of PAC; 6) Guidance through videos on the use of tablets received from the municipality hall to support all this work developed during the pandemic.

In April, the first version was built, until June there were 12 updates of the Action Plan using the digital videoconference interface. The process of building and implementing the action plan revealed learning opportunities and the recognition of potentialities, such as:

1) The systematization of the Action Plan was a great differential in the understanding by all the PAC team and EBPCDM managers, especially in the organization of planning, in the procedures for the development, and in ensuring moments of monitoring and evaluation of the actions developed ${ }^{8}$.

2) Another important aspect was that, through the systematization of remote actions, the program was able to give access to empowerment and self-care actions not only for users who were already part of the PAC, but also for the general population regardless of having a nearby hub participation ${ }^{2,3,9}$.

3) The maintenance actions to promote physical activities and body practices through different remote strategies and some linked to the PAC Instagram @ 


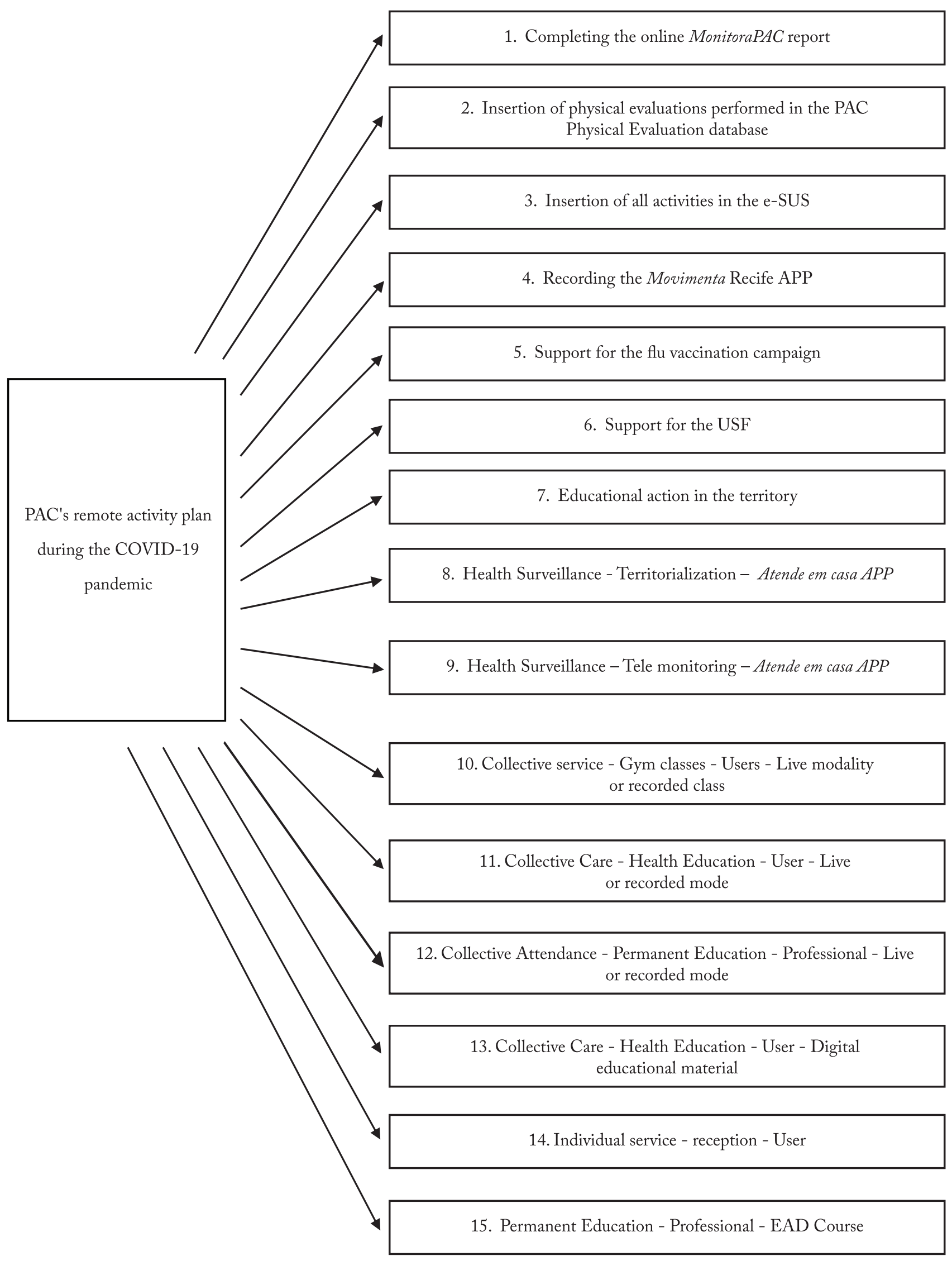

Figure 2 - Axis of the PAC-REC action Plan during the COVID-19 pandemic, Recife, Pernambuco, 2020. 
social network, as well as activities developed to its users in their respective centers ${ }^{1-3,9}$.

4) The collaboration of the PEPs in the continuity of the user's care in the RAPS ${ }^{1-4,9}$, through tele-monitoring remote individual assistance for those who were served by the Atende em Casa App.

5) Reinforcement of the performance of the PEPs as health professionals who are parts of the system whose work goes beyond their core of knowledge, being also a support for the demands of the territory, such as in the vaccine campaigns, administrative support to the FSU, itinerant action and educational activities in the territory ${ }^{2,3,9,10}$.

6) Systematization of the Permanent Education axis, through distance courses for the PEPs of the PAC, which is widely publicized, free and accessible, with the aim of professional qualification, as well as support for the needs of the service in the pandemic scenario ${ }^{9,11}$.

7) Learning of the entire team regarding new digital interfaces that could meet the needs of the action plan ${ }^{12}$. Then we observed that the Program had organized a framework of documentation guiding the work process, as well as new supports in the pedagogical action between teacher and student, which served for the remote moment, however they will also serve in the face-to-face activities in the hubs.

8) The PAC-REC can contribute to the strengthening of Health Promotion in the RAPS, working within the broader concept of health, making it possible to maintain and improve not only the physical fitness, but also promoting socio-psychosocial benefits reported by the users themselves ${ }^{3,9,10}$.

There are numerous benefits, however, as expected, there were some limitations:

1) Difficulty in quickly adapting the social relationship focused on work. The need to develop new ways of making PAC's activities available, prompted PEPs to acquire new skills, which some had immediate difficulties in adapting to, such as being able to create and produce videos in a short time ${ }^{13}$.

2) Digital accessibility for all users. Some users had difficulty regarding electronic equipment to access the internet and others did not have access to the internet ${ }^{14,15}$.

3) Building a new relationship way between the professional and the user ${ }^{13,15}$.
In conclusion, the COVID-19 is a global problem, however the PAC-REC as a reference program in the SUS has the responsibility to be a protagonist in the face of the challenges of each historical moment. In this sense, the PAC-REC action plan during the period of social isolation due to COVID-19 was built and implemented, continuing and expanding its health promotion actions for the Recife population in different ways and distributed in its 3 axes of actions.

\section{Conflict of interest}

The authors declare no conflict of interest.

\section{Authors' contributions}

Oliveira DCR and Holmes TMF, participated in the initial study design, data collection and analysis, writing and critical review of the text. Lemos EC, contributed to the initial study design, data analysis, writing and critical review of the text. Tassitano RM, contributed to the initial study design, data analysis, writing and critical review of the text. Pajeú RB, Oliveira GS, Souza LEN and Santos RWY participated in the initial study design, data collection and analysis, writing and critical review of the text. Silva CHBG, Silva MP, Campos GMC and Silva RAM, was responsible for the literature search, data collection and critical text review. All authors approved the final version.

\section{Acknowledgment}

The authors would like to thank the professionals of ACP, the City of Recife.

\section{References}

1. Recife. Secretaria Municipal de Saúde. Decreto no 19.808 de 03 de Abril de 2003. Programa Academia da Cidade. [citado em 2020 Jul 08]. Disponível em: http://www.legiscidade. recife.pe.gov.br/decreto/19808/.

2. Brasil. Ministério da Saúde. Política Nacional de Atenção Básica. Portaria no 2.436, de 21 de Setembro de 2017. [citado em 2020 Jul 08]. Disponível em: https://bvsms.saude.gov.br/ bvs/saudelegis/gm/2017/prt2436_22_09_2017.html.

3. Brasil. Ministério da Saúde. Redefinição da Política Nacional de Promoção a Saúde. Departamento de Análise de Situação em Saúde. Novembro, 2014. [citado em 2020 Jul 11]. Disponível em: https://bvsms.saude.gov.br/bvs/saudelegis/ gm/2014/prt2446_11_11_2014.html.

4. Brasil. Ministério da Saúde. Portaria no 2.681, de 7 de Novembro de 2013. Redefine o Programa Academia da Saúde no âmbito do Sistema Único de Saúde (SUS). [citado em 2020 Jul 11]. Disponível em: http://bvsms.saude.gov.br/ bvs/saudelegis/gm/2013/prt2681_07_11_2013.html.

5. FIOCRUZ. Pernambuco. Observatório COVID-19. Impactos sociais, econômicos, culturais e políticos da pandemia. [citado em 2020 Jul 12]. Disponível em: https:// portal.fiocruz.br/impactos-sociais-economicos-culturais-epoliticos-da-pandemia. 
6. Pernambuco. Governo do Estado. Decreto no 48.822, de 17 de Março de 2020. [citado em 2020 Jul 12]. Disponível em: https://legis.alepe.pe.gov.br/texto.aspx?tiponorma $=6 \& \mathrm{nu}$ mero $=48822 \&$ complemento $=0 \& a n o=2020 \&$ tipo $=\& u r l=$.

7. Recife. Prefeitura do Recife. Gabinete de Imprensa. PCR suspende funcionamento das academias públicas e dos três Compaz. [citado em 2020 Jul 12]. Disponível em: http://www2.recife.pe.gov.br/noticias/16/03/2020/pcrsuspende-funcionamento-das-academias-publicas-e-dostres-compaz-partir-desta\#: :text=16.03.20\%20\%2D\%20 18h28-,PCR\%20suspende $\% 20$ funcionamento\%20das $\% 20$ academias $\% 20$ p \% C 3\%BAblicas $\% 20$ e $\% 20$ dos, a $\% 20$ partir\%20desta\%20quarta\%20(18)\&text=Mais\%20doze\%20 medidas\%20foram $\% 20$ anunciadas, segunda $\% 2$ Dfeira $\% 20$ (16).\&text=A\%20tr\%C3\%AAs\%20unidades $\% 20$ dos $\% 20$ Centros,as\%20atividades\%20na\%20mesma\%20data.

8. Samico I, Felisberto E, Figueiró AC, Frias PG. Avaliação em saúde: bases conceituais e operacionais. ed. padrão. Recife: Medbook, 2010. p. 196.

9. Brasil. Congresso Nacional. Lei no 8.080, de 19 de Setembro de 1990. [citado em 2020 Jul 21]. Disponível em: http:// www.planalto.gov.br/ccivil_03/leis/18080.htm.

10. Carvalho FFB, Carvalho YM. Outros lugares e modos de "ocupação" da Educação Física na Saúde Coletiva/Saúde Pública. Pensar a Prática. 2018; 21(4): 957-67.
11. Brasil. Ministério da Saúde. Política Nacional de Educação Permanente em Saúde: o que se tem produzido para o seu fortalecimento? $1^{\text {a }}$ ed. Brasília. 2018. [citado em 2020 Jul 25]. Disponível em: https://bvsms.saude.gov.br/bvs/ publicacoes/politica_nacional_educacao_permanente_ saude_fortalecimento.pdf.

12. Nantes EAS, Junior ALG, Pinho ECS, Porto IMN, Simm JFS, Vitello MGF. Percepções de professores da educação a distância sobre a tecnologia e sua aplicabilidade pedagógica. Revista Conhecimento Online. 2019;11(2):149-70.

13. Souza CTV, Santana CS, Ferreira P, Nunes JA, Teixeira MLB, Gouvêa MIFS. Cuidar em tempos da COVID-19: lições aprendidas entre a ciência e a sociedade. 2020; 6 (6): e00115020.

14. Matias TS, Dominski FH. The COVID-19 pandemic challenges physical activity with two emerging paradigms. Rev Bras Ativ Fís Saúde. 2020;25:e0113.

15. Ceccon RF, Schneider IJC. Tecnologias leves e educação em saúde no enfrentamento à pandemia da COVID-19. SciELO Public Health. 2020. [citado em 2020 nov 5]. Disponível em: <https://preprints.scielo.org/index.php/scielo/preprint/ view/136>.

\section{Quote this article as:}

Oliveira DCR, Holmes TMF, Lemos EC, Tassitano RM, Pajeú RB, Oliveira GS, Souza LEN, Santos RWY, Silva CBG, Silva MP, Campos GMC, Silva RAM. Planning, development, monitoring and evaluation of the Academia da Cidade do Recife action plan during COVID-19. Rev Bras Ativ Fis Saúde. 2020;25:e0160. DOI: 10.12820/rbafs.25e0160 